\begin{tabular}{|l|l|l|l|l|}
\hline Jurnal Penelitian \& PKM & Juli 2017 & Vol 4, No: 2 & Hal: $129-389$ & ISSN \\
\hline
\end{tabular}

\title{
RESILIENSI REMAJA BERPRESTASI DENGAN LATAR BELAKANG ORANG TUA BERCERAI
}

\author{
STUDI KASUS PADA SISWA - SISWI BERPRESTASI DENGAN LATAR BELAKANG ORANG \\ TUA BERCERAI DI SMA NEGERI 1 MARGAHAYU
}

\author{
OLEH: \\ SALSABILA WAHYU HADIANTI ${ }^{1}$, R. NUNUNG NURWATI'², RUDI SAPRUDIN DARWIS ${ }^{3}$ \\ ${ }^{1}$ Mahasiswa S1 Program Studi Kesejahteraan Sosial, Fakultas Ilmu Sosial dan Ilmu Politik, Universitas \\ Padjadjaran, Jl. Raya Bandung - Sumedang Km. 21 Jatinangor 45363. \\ ${ }^{2}$ Dosen Program Studi Kesejahteraan Sosial, Fakultas Ilmu Sosial dan Ilmu Politik, Universitas Padjadjaran, \\ Jl. Raya Bandung - Sumedang Km. 21 Jatinangor 45363. \\ ${ }^{3}$ Dosen Program Studi Kesejahteraan Sosial, Fakultas Ilmu Sosial dan Ilmu Politik, Universitas Padjadjaran, \\ Jl. Raya Bandung - Sumedang Km. 21 Jatinangor 45363.

\section{Swhyhadianti02@gmail.com¹,nngnurwati@yahoo.com²,rsdarwis@gmail.com³}

\begin{abstract}
ABSTRAK
Perceraian (divorce) dalam hal ini merupakan suatu kejadian yang tentunya tidak dikehendaki oleh suami istri, khususnya anak. Perceraian yang dialami oleh orang tua tentunya memberikan konsekuensi atau dampak yang begitu besar pada kehidupan anak yakni seperti meliputi perasan sedih, ketakutan, depresi, marah, maupun kebingungan. Dampak perceraian tersebut akan semakin dirasakan ketika anak sudah memasuki tahap perkembangan remaja. Hal ini karena pada tahap remaja, anak mengalami perkembangan baik secara kognisi maupun emosi. Selain itu, masa remaja juga dianggap sebagai masa transisi atau masa peralihan dari masa kanak - kanak menuju masa dewasa. Masa transisi ini tentunya menimbulkan beragam kondisi stress baik yang berasal dari internal maupun eksternal remaja bersangkutan. Dalam konteks remaja yang mengalami orang tua bercerai, perceraian orang tua diartikan sebagai salah satu bentuk tekanan yang ditimbul dari eksternal yang dapat menimbulkan stress bagi remaja. Sehingga dapat disimpulkan, bahwa remaja dengan latar belakang orang tua bercerai mengalami beban stress yang lebih besar dibandingkan dengan remaja yang berasal dari keluarga yang utuh. Beragam tekanan serta dampak yang muncul akibat perceraian orang tua tentunya memerlukan sebuah strategi yang disebut sebagai kemampuan resiliensi. Pada konteks remaja berprestasi dengan latar belakang orang tua bercerai telah menunjukan bahwa remaja telah memiliki kapasitas untuk menghadapi, mencegah, meminimalkan, bahkan mengalihkan dampak - dampak yang merugikan akibat perceraian kearah yang positif yakni dengan berprestasi.
\end{abstract}

Kata kunci : Perceraian, Remaja, Beprestasi, Resiliensi.

\begin{abstract}
ABSTRAC
Divorce is an event which certainly isn't desired by the husband - wife, especially for children. Divorce giving the consequences or impact for child's life example like made children feelt sadness, fear, depression, anger, or confusion. This impact will increasingly be felt when children have entered the stage of adolescents. Because in this stage, children have experience for developing their cognition or emotion. In addition, adolescence is also a transitional period. This transition period of course give some conditions of stress that comes from both internal and external teenagers concerned. In the context of teens who are having divorced parents, divorce is defined as one form of pressure from external which can cause stress for adolescents. The conclusion is, that the teenager with a background of divorced parents suffered greater stress loads compared to teenagers who come from families that are intact. Various pressures and impacts arising out of divorce parents surely need requires a strategy referred to as the ability of resiliensi. In the context of adolescent overachievers against a background of divorced parents have shown that teenagers already have the capacity to deal with,
\end{abstract}


prevent, minimize, even divert the impact - the impact of the adverse consequences of divorce towards positive.

Keywoard : : Divorce, Adolescene, Achievement, Resilience.

\section{Pendahuluan}

Perceraian (divorce) merupakan suatu kejadian yang tentunya tidak dikehendaki oleh suami - istri, khususnya anak. Dalam persepsi anak, perceraian dianggap sebagai sebuah mimpi buruk karena mereka menganggap bahwa perceraian yang dialami oleh orang tuanya merupakan sebuah tanda kematian bagi keutuhan keluarganya. Dalam hal ini, perceraian tentunya menimbulkan konsekuensi yang harus mereka hadapi yakni menerima kesedihan dan perasaan kehilangan yang mendalam akibat perceraian yang dialami oleh orang tua mereka. Brooks (2011) menjelaskan bahwa saat terjadinya perceraian orang tua, anak memberikan reaksi emosional yang mana hal ini biasa terjadi pada anak semua usia, mencakup kesedihan, ketakutan, depresi, amarah, dan kebingungan.

Perceraian yang dialami oleh orang tua tentunya membawa perubahan terhadap struktur dan relasi dalam keluarga. Salah satu perubahan struktur keluarga yang diakibatkan oleh perceraian dan dirasakan oleh anak adalah kondisi dimana anak tidak lagi tinggal bersama kedua orang tuanya pasca perceraian. Lebih lanjut Ihromi (1999) menegaskan bahwa pada masa setelah perceraian merupakan periode paling sulit bagi anak. Kondisi tersebut tentunya menuntut anak untuk dapat mengembangkan kemampuan dirinya agar dapat beradaptasi dengan situasi pasca perceraian.

Beragam macam persoalan dialami anak pasca terjadinya perceraian orang tua, salah satu permasalahan yang dialami anak pasca terjadinya perceraian adalah stigma masyarakat terhadap anak - anak yang hidup dengan latar belakang orang bercerai. Hingga saat ini, masih banyak ditemukan masyarakat yang dengan mudah memberikan stigma atau melakukan pelabelan bahwa tindakan delikuen banyak diakibatkan oleh anak dengan latar belakang orang tua bercerai. Sebagaimana yang dikemukakan oleh Kartono (2014) yang menjelaskan bahwa setiap perubahan dalam relasi personal antara suami istri menjurus pada arah konflik dan perceraian, maka perceraian merupakan faktor penentu bagi pemunculan kasus - kasus neurotik, tingkah laku a-sosial dan kebiasaan - kebiasaan delikuen.
Selanjutnya Nadeak (2014) menjelaskan terkait data mengenai struktur keluarga anak nakal menyebutkan bahwa lebih dari separuh anak nakal berasal dari keluarga yang single parent bahkan $19,5 \%$ berasal dari keluarga broken home. Dengan banyaknya data - data yang menunjukan bahwa tindakan delikuen pada remaja dipengaruhi oleh faktor perceraian, membuat banyak masyarakat menggeneralisasikan bahwa anak dengan latar belakang orang tua bercerai sudah pasti melakukan tindakan yang menyimpang atau dianggap sebagai pelaku kenakalan remaja.

Dalam hal ini yang perlu digaris bawahi adalah seringkali masyarakat memberikan stigma atau pelabelan tanpa alasan yang jelas dan dilakukan secara generalisasi. Artinya, masyarakat dalam hal ini memperlakukan anak sesuai dengan labelnya secara menyeluruh tanpa terkecuali misalnya sebagaimana yang telah dikemukakan pada paragraf sebelumnya bahwa masyarakat memberikan label kepada anak - anak dengan latar belakang orang tua bercerai sebagai anak yang nakal, padahal sebenarnya tidak semua anak dengan latar belakang orang tua bercerai adalah anak yang nakal.

Berangkat dari asumsi tersebut, sebenarnya diperlukan sebuah pemahaman baru bahwa pada kenyataannya tidak menutup kemungkinan perceraian dapat dipandang dari sisi yang lebih positif. Perceraian yang dialami oleh orang tua dimasa lalu sebenarnya dapat dijadikan motivasi bagi anak agar terhindar dari pengalaman buruk yang dialami oleh orangtuanya dimasa yang akan datang. Pendapat serupa juga dikemukakan oleh Amadea dkk (2015) yang menjelaskan bahwa pada saat remaja dihadapkan oleh situasi kedua orang tuanya yang bercerai, maka hal tersebut dapat dijadikan motivasi dalam dirinya agar kelak kehidupannya di masa depan tidak "gagal" seperti orang tuanya.

Amanto (2000) menjelaskan bahwa perceraian dapat menjadi pengalaman yang memberikan kesempatan anak untuk mendapatkan kebahagiaan dan menyelamatkan dari lingkungan rumah yang disfungsional. Lebih lanjut, Baskoro (2008) menjelaskan terkait perceraian dapat mendorong anak kearah positif yakni dimana anak menjadi lebih optimis dalam 
menghadapi masa depannya. Dalam hal ini, anak dapat memiliki prestasi yang bagus dalam bidang akademiknya serta memiliki kemampuan dalam berorganisasi. Pendapat tersebut tentunya menjadi bukti bahwa sebenarnya perceraian tidak selalu memiliki dampak buruk bagi anak. Justru sebaliknya, perceraian dapat menjadi dorongan positif bagi anak salah satunya yakni untuk terus berprestasi.

Barack Husein Obama dan Susilo Bambang Yudyohono (SBY) merupakan salah satu contoh potret bagaimana seorang anak dengan latar belakang orang tua bercerai dapat bangkit dari masa lalunya (Fitriana, 2012). Sebagai anak yang tumbuh dan berkembang dari keluarga yang bercerai justru membentuk mereka menjadi pribadi yang cerdas dan berprestasi sejak muda. Dari perjalanan dua tokoh terkemuka ini dapat menunjukan bahwa perceraian yang dialami oleh orang tuanya dimasa lalu tidak serta merta membuat mereka terpuruk secara berkepanjangan atau melakukan tindakan yang bersifat delikuen.

Kemampuan dua tokoh tersebut untuk dapat bangkit dari keterpurukan dari situasi sulit akibat perceraian orang tua dapat disebut sebagai kemampuan resiliensi. Lebih lanjut Reivich \& Shatte dalam Dewanti \& Suprapti (2012) menjelaskan bahwa resiliensi dapat diartikan sebagai kemampuan untuk mengatasi dan beradaptasi ketika menghadapi kejadian yang berat atau masalah yang terjadi dalam kehidupan.

Kemampuan resiliensi dalam hal ini juga diperlukan dalam mengatasi dampak perceraian orang tua, mengingat perceraian merupakan salah satu hal yang sulit diterima oleh anak. Hal yang sama juga dikemukakan oleh Woolfolk (2008) yang menjelaskan bahwa perceraian adalah sesuatu yang tidak mudah bagi anak khususnya bagi remaja. Untuk itu dengan adanya kemampuan resiliensi seseorang diharapkan dapat melewati perubahan dan tekanan hidup yang dialaminya secara lebih efektif, termasuk dalam proses melewati kondisi pasca perceraian orang tua.

Subjek penelitian yang dipilih dalam proses penelitian ini adalah remaja. Remaja dipilih menjadi subjek penelitian mengingat masa remaja merupakan masa transisi dimana anak mengalami banyak perubahan dalam hidupnya. Pada masa ini anak dirasa sudah mampu menganalisis pemikirannya sendiri, mengetahui perasaannya, dan memberikan reaksi mereka terhadap orang lain. Brooks (2011) menjelaskan bahwa masa remaja merupakan periode kerentanan dan kesempatan. Pada masa ini anak juga merasakan stress karena banyaknya perubahan.

Emery (1999) dalam Dewanti dan Suprapti mengungkapkan bahwa seiring peningkatan dari waktu ke waktu setelah perceraian, masa remaja merupakan masa yang paling sulit bagi anak anak dari keluarga bercerai. Lebih dalam Dewanti \& Suprapti (2014) menjelaskan bahwa ketika orang tua bercerai, remaja memiliki tugas yang berat untuk menyesuaikan perubahan saat menghadapi perceraian orang tua. Sebagaimana telah dijelaskan pada paragraf sebelumnya, bahwa perceraian dapat dikatakan sebagai situasi sulit bagi seorang anak. Sehingga resiliensi pada remaja dengan latar belakang orang tua bercerai sangat diperlukan.

Karakteristik remaja berprestasi dengan latar belakang orang tua bercerai dipilih dalam proses penelitian ini mengingat bahwa remaja berprestasi tentunya telah melakukan proses, mengembangkan kapasitas atau kemampuan dalam dirinya untuk melakukan penyesuaian pasca kejadian perceraian yang dialami oleh orang tuanya. Selain itu, hal tersebut juga telah menunjukan bahwa anak memiliki kapasitas untuk menghadapi, mencegah, meminimalkan, bahkan mengalihkan dampak - dampak yang merugikan yang diakibatkan oleh perceraian kearah yang lebih positif, yakni dengan cara berprestasi. Sebagaimana yang dikemukakan oleh Linquanti dalam Masdianah (2010) menjelaskan bahwa dengan adanya resiliensi walaupun anak dihadapkan dengan kejadian - kejadian yang tidak menyenangkan ia tidak mengalami kegagalan dalam hal akademisnya. Keterkaitan antara perceraian, resiliensi, dan kemampuan berprestasi pada anak dengan latar belakang orang tua bercerai juga diungkapkan pada artikel yang ditulis oleh Octaria dkk. Octaria dkk (2007) menjelaskan pada contoh anak yang orang tuanya bercerai sebanyak $75 \%$ dari mereka mampu bangkit dan berprestasi.

\section{Perceraian}

Perceraian dapat diartikan sebagai berakhirnya atau putusnya hubungan antara suami - istri. Perceraian dalam hal ini, merupakan pilihan terakhir ketika konflik rumah tangga tidak dapat ditangani oleh kedua belah pihak yakni suami istri. Lembaga Demografi Universitas Indonesia (1981:154-155) menjelaskan bahwa perceraian banyak dipengaruhi oleh faktor demografi lainnya, 
seperti umur, kelompok etnik, asal daerah, kota, desa dan sebagainya. Faktor yang menjadi penunjang dari perkawinan dan perceraian antara lain kondisi ekonomi, pendidikan, dan faktor legal atau tidaknya perkawinan dan perceraian. Faktor lamanya perkawinan sangat penting dalam menghitung potensi dan stabilitas perkawinannya.

\section{Masa Remaja}

Masa remaja merupakan masa transisi dari masa kanak - kanak menuju masa dewasa. Pada masa ini terjadi perubahan pada diri anak meliputi aspek biologis, psikologi, sosial, dan spiritual. Mengutip pendapat Hurlock (1991) dijelaskan bahwa masa remaja (adolescene) memiliki makna yang lebih luas mencakup kematangan mental, emosional, sosial dan fisik. Lebih lanjut mengutip pendapat Hill (Hill dalam Jatnika, 2016) dijelaskan bahwa terdapat tiga hal yang membedakan remaja dari kelompok usia lainnya, diantaranya diawali dengan kemunculan pubertas, berkembangannya kemampuan berfikir, dan pergeseran menuju peran baru dalam masyarakat dimana perubahan dalam perkembangan seorang remaja merupakan hasil dari proses biologis (fisik), kognitif dan sosial yang saling terikat dan mempengaruhi.

\section{Resiliensi}

Resiliensi dalam hal ini dapat didefinisikan sebagai kemampuan atau kapasitas, proses, serta hasil adaptasi seseorang terhadap perubahan, tekanan, atau kekecewaan yang dialaminya dengan cara yang lebih positif. Resiliensi juga dapat diartikan sebagai kemampuan individu untuk dapat bangkit kembali setelah mengalami situasi traumatis. Lebih lanjut Petranto (2005) menjelaskan bahwa resiliensi adalah seberapa tinggi daya tahan seseorang dalam menghadapi stress dan kesengsaraan dan ketidakberuntungan. Sedangkan menurut Grotberg dalam Desmita (2006) menjelaskan bahwa resiliensi adalah kemampuan atau kapasitas insani yang dimiliki seseorang, kelompok, atau masyarakat yang memungkinkannya untuk menghadapi, mencegah, meminimalkan dan bahkan menghilangkan dampak - dampak yang merugikan dari kondisi kondisi yang tidak menyenangkan, atau bahkan mengubah kondisi kehidupan yang menyengsarakan menjadi suatu hal yang wajar untuk diatasi. Resiliensi dalam hal ini terbagi menjadi sumber - sumber pembentukan resiliensi, faktor - faktor yang mempengaruhi resiliensi, kapasitas resiliensi, dan karakteristik individu yang resilien.

Berdasarkan uraian yang telah dipaparkan pada paragraf sebelumnya, maka tujuan dari penelitian ini yakni sebagai berikut :

1. Untuk menggambarkan bagaimana sumber - sumber pembentukan resiliensi pada remaja berprestasi dengan latar belakang orang tua bercerai;

2. Untuk mengambarkan bagaimana faktor faktor yang mempengaruhi resiliensi pada remaja berprestasi dengan latar belakang orang tua bercerai;

\section{Metode}

Metode yang digunakan dalam proses penelitian ini adalah studi literatur, yakni dalam proses penghimpunan data dan sumber - sumber yang berhubungan dengan topik yang dikaji didapat peneliti melalui berbagai sumber yakni seperti jurnal, buku dokumentasi, internet, maupun pustaka.

\section{Hasil dan Pembahasan}

Ketika orang tua bercerai, anak seringkali menjadi korban. Dampak yang ditimbulkan dari perceraian orang tua tentunya berpengaruh pada kehidupan atau perkembangan anak dan dapat mempengaruhi aspek biologis, psikologis, sosial dan spiritual anak. Sebagaimana yang dikemukakan oleh Hutchinson dalam Apsari (2015) terkait pengaruh perceraian merupakan salah satu faktor penghambat perkembangan anak :

"Selain orang tua, ada juga faktor lain yang dapat menjadi faktor - faktor resiko yang dapat menghambat perkembangan anak, diantaranya adalah kemiskinan, disiplin yang tidak efektif, perceraian dan kekerasan." (Apsari, 2015 : 35)

Kemampuan resiliensi dalam hal ini sangat diperlukan dalam mengatasi dampak perceraian orang tua, mengingat perceraian merupakan salah satu hal yang sulit diterima oleh anak. Hal yang sama juga dikemukakan oleh Woolfolk (2008) yang menjelaskan bahwa perceraian adalah sesuatu yang tidak mudah bagi anak khususnya bagi remaja. Untuk itu dengan adanya kemampuan resiliensi seseorang diharapkan dapat melewati perubahan dan tekanan hidup yang dialaminya 
secara lebih efektif, termasuk dalam proses melewati kondisi pasca perceraian orang tua.

Penelitian ini mencoba mengkaji terkait bagaimana sumber - sumber resiliensi dan faktor - faktor yang mempengaruhi resiliensi yang dimiliki anak berprestasi dengan latar belakang orang tua bercerai. Pola - pola tersebut tentunya dapat menuntun kita untuk dapat memahami tentang bagaimana seorang remaja dengan latar belakang orang tua bercerai dapat bangkit dari tekanan hidup yang ditimbulkan akibat perceraian, meminimalkan dampak, bahkan mengalihkan dampak - dampak yang merugikan akibat perceraian dengan cara yang lebih positif yakni dengan berprestasi.

\section{Sumber - Sumber Pembentukan Resiliensi}

Sumber - sumber pembentukan resiliensi menurut Grotberg (1995) menjadi tiga bagian yakni $I$ am, I have, dan $I$ can. Dengan mengambil contoh kasus seorang remaja dengan latar belakang orang tua bercerai, yakni berinisial BIART dalam penelitian yang ditulis oleh Patrcia (2016) peneliti mencoba menggambarkan tentang bagaimana sumber - sumber pembentukan resiliensi pada diri remaja dengan latar belakang orang tua bercerai yang selanjutnya dijelaskan sebagai berikut :

1. I am : Yakin dengan kemampuan yang dimiliki; penuh harapan dan keinginan; selalu menganggap orang lain sebagai teman; yang terpenting adalah sikapnya terhadap orang lain; memiliki gambaran diri yang positif.

2. I have : Ada keterlibatan nenek; lingkungan yang mendukung; memiliki sumber dukungan lain seperti ibu, pacar, dan teman; ada peraturan dari ibu dalam bergaul dan beribadah; dukungan dari pasangan; mengikuti komunitas yang bermanfaat; sumber ekonomi dan akses layanan kesehatan terpenuhi.

3. I can : Mampu secara akademik; mampu beradaptasi; memiliki tujuan dalam hidup; mampu memahami perasaan dan mengatasinya; berupaya untuk mengubah sesuatu; memiliki berbagai cara untuk mengatasi masalah; dan mampu menerima keadaan.

\section{Faktor - Faktor yang Mempengaruhi Resiliensi}

Everal Robbin (2006) menjelaskan terdapat tiga faktor yang mempengaruhi resiliensi yakni faktor individual, faktor keluarga, faktor komunitas. Masih mengambil contoh kasus yang sama yakni BIART ketiga faktor tersebut digambarkan sebagai berikut :

1. Faktor individual : dalam hal ini BIART menunjukan bahwa dirinya telah kapasitas kemampuan untuk mengembangkan dirinya, selain itu dari hasil penelitian menunjukan bahwa BIART memiliki kemampuan interpersonal yang baik.

2. Faktor keluarga, pasca terjadinya perceraian orang tua BIART diasuh oleh neneknya, selain itu hubungan yang antara BIART dan ayah ibunya terbangun dengan baik pasca terjadinya perceraian.

3. Faktor komunitas, yakni dengan mengikuti kegiatan komunitas yang bermanfaat.

\section{Simpulan/ Rekomendasi}

Resiliensi dalam hal ini memiliki fungsi bagi kehidupan manusia antara lain untuk mengatasi, melewati, serta bangkit dari situasi menekan; mengalihkan dampak negatif dari situasi yang menekan menjadi dampak yang positif; serta guna mencapai kehidupan yang lebih baik.

Resiliensi tentunya sangat diperlukan dan perlu untuk dikembangkan ketika seorang anak atau remaja dihadapkan pada kondisi perceraian orang tua. Hal ini karena, dengan adanya resiliensi dampak - dampak negatif yang ditimbulkan akibat perceraian dapat terminimalisir, selain itu anak atau remaja dapat mengembangkan dirinya ke arah yang lebih positif.

Kemampuan resiliensi pada remaja dengan latar belakang orang tua bercerai tidak semata mata terbentuk secara tiba - tiba. Dalam hal ini diperlukan sistem sumber yang dapat mendukung proses terbentuknya resiliensi, diantaranya yakni baik yang terbentuk dalam diri sendiri, lingkungan keluarga, maupun lingkungan sosial. Maka berdasarkan asumsi tersebut selanjutnya peneliti merekomendasikan beberapa hal yang bertujuan untuk meningkatkan resiliensi pada remaja, yakni sebagai berikut : 
1. Remaja dengan latar belakang orang tua bercerai harus meyakini bahwa terdapat potensi yang besar dalam dirinya untuk dikembangkan. Dengan tergalinya kemampuan resiliensi ini tentunya dapat dijadikan sebagai kekuatan (strength) yang dapat mendorong peningkatan kualitas hidup dan menghindari anak dalam melakukan tindakan menarik diri dari lingkungannya maupun menyalahkan diri sendiri (self blaming) atas perceraian yang terjadi pada orangtua yang berujung pada tindakan kenakalan remaja.

2. Perlunya pemahaman pada orang tua tentang bagaimana cara meningkatkan resiliensi pada anak. Karena dengan begitu, orang tua dapat memberikan perhatian penuh kepada anak sebagai bentuk dukungan sosial bagi anak ketika anak mengalami hambatan atau menghadapi tekanan - tekanan baik dari lingkungan internal maupun eksternal yang disebabkan oleh dampak perceraian itu sendiri.

3. Diperlukannya layanan khusus yang diberikan oleh guru konseling sekolah pada anak dengan latar belakang orang tua bercerai. Pelayanan ini diakankan bertujuan untuk memberikan perhatian penuh sebagai bentuk dukungan sosial bagi anak ketika anak mengalami hambatan atau menghadapi tekanan tekanan baik dari lingkungan internal maupun eksternal pasca terjadinya perceraian.

4. Diharapkan melalui penelitian ini masyarakat tidak lagi melakukan proses pelabelan atau generalisasi terhadap anak dengan latar belakang orang tua bercerai, karena hal tersebut dapat mempengaruhi kepribadian atau perkembangan anak anak dengan latar belakang orang tua bercerai.

\section{UCAPAN TERIMAKASIH}

Tidak lupa penulis juga mengucapkan terimakasih kepada pihak - pihak yang membantu kelancaran penyusunan artikel ini:

6. Orangtua penulis yang senantiasa memberikan semangat dan dukungannya;
7. Dr. R. Nunung Nurwati., Dra., M.S selaku dosen pembimbing yang senantiasa memberikan masukan dan semangat penulis agar dapat menyelesaikan tugas ini dengan baik;

8. Dr. Rudi Saprudin Darwis., S.Sos., M.Si selaku dosen pembimbing yang senantiasa memberikan masukan dan semangat penulis agar dapat menyelesaikan tugas ini dengan baik;

9. Dosen Mata Kuliah Penelitian Pekerjaan Sosial;

10. Teman-teman yang selalu setia membantu dalam hal mengumpulkan data-data dalam pembuatan artikel ini;

\section{DAFTAR PUSTAKA}

\section{Buku}

Apsari, Nurliana Cipta. 2015. Hak Anak Perspektif Pekerjaan Sosial. Sumedang: Unpad Press.

Baskoro, A.K. 2008. Hubungan Antara Persepsi Terhadap Perceraian Orang Tua Dengan Optimisme Masa Depan Pada Remaja Korban Perceraian. Surakarta : Universitas Muhammadiyah.

Brooks, Jane. 2011. The Process of Parenting. Yogyakarta : Pustaka Pelajar.

Desmita. 2006. Psikologi Perkembangan. Bandung : PT. Remaja Rosda Karya.

Desmita. 2009. Psikologi Perkembangan Peserta Didik. Bandung : PT. Remaja Rosda Karya.

Fitriana, Rika. 2012. Skripsi: Memahami Pengalaman Komunikasi Remaja Broken Home dengan Lingkungannya dalam Membentuk Konsep Diri. Semarang: Universitas Diponegoro.

Grotberg, E. 1995. A Guide to Promoting Resilience in Children : Strengthening The Human Spirit. America : Benard Van Leer Foundation.

Hurlock, E.B. 1990. Psikologi Perkembangan. Jakarta : Erlangga.

Ihromi, T.O. 1999. Bunga Rampai Sosiologi Keluarga. Jakarta : Yayasan Obor Indonesia. 


\begin{tabular}{|c|c|c|c|c|}
\hline Jurnal Penelitian \& PKM & Juli 2017 & Vol 4, No: 2 & Hal: $129-389$ & $\begin{array}{c}\text { ISSN } \\
2442-448 X(\mathrm{p}), 2581-1126(\mathrm{e})\end{array}$ \\
\hline
\end{tabular}

Jatnika, Dyana C \& dkk. 2016. Pekerjaan Sosial Koreksional Kasus Proses Integrasi Anak Didik LPKA Ke Masyarakat. Bandung : Unpad Press.

Kartono, Kartini. 2014. Patologi Sosial 2 Kenakalan Remaja. Jakarta : PT. Grafindo Persada.

Lembaga Demografi UI. 1981. Dasar - Dasar Demografi. Jakarta : Fakultas Ekonomi UI.

Patricia. 2016. Skripsi : Resiliensi Remaja yang Orang Tuanya Bercerai. Yogyakarta : Universitas Sanata Darma.

Raharjo, ST. 2015. Assessment untuk Praktik Pekerjaan Sosial dan Kesejahteraan Sosial. Bandung: Unpad Press 2015. Dasar Pengetahuan Pekerjaan Sosial. Bandung: Unpad Press. 2015. Keterampilan Pekerjaan Sosial: Dasar-dasar. Bandung, Unpad Press.

Woolfolk, Anita. 2008. Educational Psychology. USA: Pearson Education, Inc.

\section{Jurnal}

Amadea, Trizilvania Aziza dkk. (n,d). Perkembangan Perilaku Kepribadian Remaja Dengan Latar Belakang Kedua Orang Tua Bercerai. Jurnal Vol. 2 No.3 Hal. $301-444$.

Atmanto, P.R. 2000. The Consequences of Divorce for Adults and Childrens. Journal of The Marriage and The Family. Vol. 62, No. 4 p. 1269 $-1287$.

Dewanti, Ayu., Veronika Suprapti. 2014. Resiliensi Remaja Putri Terhadap Problematika Pasca Orang Tua Bercerai. Jurnal Psikologi Pendidikan dan Perkembangan Vol. 3 No.3 Desember 2014. Hal $164-171$.

Nadeak, Tiara Farita S., dkk. 2014. Fenomena "Anak Nakal" di Rungkut Surabaya. Jurnal Vol. 02 No. 02 Tahun 2014.

\section{Artikel}

Octaria, Andini dkk. 2007. Gambaran Resiliensi dan Faktor - Faktor Pendukung Resiliensi. 